\title{
EMOTSIOONISÕNAD TÖISES KESKKONNAS - MILLEST KÕNELEVAd LOETELUKATSETE TULEMUSED?
}

\author{
Ene Vainik
}

Ülevaade. Artiklis võrreldakse emotsioonisõnade esiletulekut 2001. aastal läbi viidud loetelukatsetes tööl ja mujal. Hetketunnete ja emotsioonidega seotud tegusõnade loetelukatsete tulemuste semantilise analüüsi põhjal osutus, et katse läbiviimise koht on mõningal määral mõjutanud emotsioonisõnade meenumist, seda eriti konkreetsete emotsioonide ja emotsioonidega assotsiatiivselt seotud sõnavara osas. Hetketundeid loetlevad sõnad olid töises keskkonnas hinnangult vastuolulisemad kui mujal, tegusõnade puhul tuli tööl esile arvukam verbaalset suhtlust ja eriti hinnangulist suhtlemist kirjeldav sõnarühm. Võimalik, et töises keskkonnas kanaliseeruvad emotsioonid hinnangulisse suhtlusse, millega taasluuakse ja hoitakse alal sellele keskkonnale omast hierarhilist suhtemudelit."

Võtmesõnad: antropoloogiline lingvistika, semantika, pragmaatika, eesti keel

\section{Lähtekohad ja eesmärk}

Artikkel põhineb ettekandel, mis peeti konverentsil teemaga "Keel töises suhtluses" (Vainik 2006b). Antud pealkiri lubab keelt mõista nii uurimisobjekti kui meediumina, mille vahendusel on võimalik midagi teada saada töise suhtluse eripärade kohta. Käesolevas artiklis ongi võetud just viimane hoiak - eesmärgiks on välja selgitada töö juures ilmnevad keeleainese esiletuleku eripärad. Lähtutakse eeldusest, et töise suhtluse spetsiifikat saab eritleda üksnes kõrvutades seda "mittetöise" suhtluse keelekasutusega. Kui muud tingimused on samad ja varieerub ainult keelefaktide ilmsikstuleku situatiivne kontekst, siis on just see suure tõenäosusega erinevuste põhjuseks. 
Järgnevas võrreldakse läbivalt töises ja mittetöises keskkonnas kogutud keeleandmeid. Artikli ainese moodustab mitte otseselt dokumenteeritud keelekasutuse, vaid eesti keele emotsioonisõnade loetelukatsete tulemuste semantiline analüüs. Loomulikult põhinevad kõik artikli lõpus esitatud kokkuvõtted ja arutlus vaid emotsioonisõnade esiletuleku erinevustel loetelukatsetes, laienemata otseselt kogu keelelisele suhtlusele töö juures. Etteruttavalt võib siiski öelda, et keeleline suhtlemine kui tegevus leidis loetelukatses emotsioonidega seoses märkimisväärselt palju mainimist. Seega keel meediumina (loetelukatsed) peegeldas emotsioonidega seoses osati üllatavaltki tagasi keelekasutuse protsessi.

\section{Uurimisprobleemi olemus}

2001. aastal läbiviidud emotsioonisõnavara loetelukatsete seerias (Vainik 2001) ilmnes märgatav erinevus töökohas ja mujal intervjueeritud tööealiste (20-65) informantide emotsiooninimetuste esmases loetelukatses: töö juures intervjueeritutele meenus emotsiooninimetustest märgataval määral vaid viha, sellal kui mittetöises keskkonnas loetleti enam-vähem võrdselt kõiki eestikeelseid emotsioonide põhinimetusi (armastus, rõõm, viha, kurbus) (Vainik, Orav 2005).

Kirjanduses on loetelukatsete tulemusi mõjutavate teguritena nimetatud sõnade omadusi nagu lühidus, sagedus korpustes (Zammuner 1998) ja inimgruppide omadusi nagu eesmärgid, elukutse või tegevusala ja sellega seotult sugu (Ross, Medin 2005). Et tulemuse jaoks võiks olla oluline ka katse toimumise koht, on seni vähekäsitletud aspekt. Käesolevast artiklis lähtutakse just sellest hüpoteesist.

Selleks, et välja selgitada, kas emotsioonikategooria liikmete selektiivne meenumine töökohas oli juhuslik või seotud mingit sorti üldisema emotsionaalse tendentsiga, analüüsitakse käesolevas artiklis semantiliselt samas 2001. a loetelukatsete seerias läbi viidud hetketunnete ja emotsioonidega seotud tegusõnade loetelukatsete tulemusi.

\section{Meetod ja valim}

Andmed koguti antropoloogilises lingvistikas kasutatava välimeetodiga, mis on mõeldud mingi valdkonna nn aktiivse sõnavara kogumiseks (Sutrop 2001, Davies, Corbett 1995). Ajalise piiranguta vaba loetlemise ülesannetes saab ainsaks keelelise produktsiooni piirajaks katseisikute lühimälu maht ja assotsiatsioonide seostumine küsitud kategooriaga. Kõnealuses hetketunnete loetelukatses tuli katseisikutel loetleda tundeid või emotsioone, mida nad küsitlemise hetkel kogesid. Emotsioonidega seotud tegusõnade loetelukatses tuli katseisikutel loetleda verbe, mis nende jaoks seostusid emotsioonidega. Andmete edasises töötluses grupeeriti mõlema katse tulemused eraldi semantiliselt ja arvutati semantiliste rühmade esiletuleku suhtelised osakaalud. ${ }^{1}$ Semantiliste rühmade esiletuleku võrdlusel kummaski andmete kogumise situatiivses kontekstis (tööl vs. mujal) põhinevadki järgnevas esitatud tulemused. Mõistagi ei saa pidada uurija keeletundel põhinevat semantilist jaotust absoluudiks ega eritletud tähendusrühmi üksteist välistavateks. Oluline on, et mõlema katse puhul on kasutatud samu kriteeriume, mis tulemusena toovad

1 Seega loobuti seekord konkreetsete sõnade esilduvuse eritlemisest kognitiivse esilduvuse indeksi (Sutrop 2001) abil, mida autor on kasutanud mitmetes varasemates artiklites (nt Vainik 2002a, 2002b). 
välja ainestiku semantilise liigenduse põhitendentsid ja küsitluskohast tingitud erinevused neis.

Loetelukatses osales 100 katseisikut vanuses 14-88 aastat. Käesolevas uurimuses kõrvutati neist vaid tööealiste isikute (20-65) loetelusid, keda oli kokku 72. Töö juures küsitletuid oli 46 ja mujal (nt kodudes, polikliinikus, teenindusasutustes) küsitletuid oli 26. Tööl küsitletute hulgas oli rohkem mehi ja mujal naisi. Varasem kontroll on näidanud, et mõlemast soost inimesed nimetasid täiesti sarnaselt töö juures esmalt viha ja alles seejärel teisi emotsioone (Vainik, Orav 2005), sama sarnast käitumist eeldati ka teistest loetelukatsetest. Töö juures küsitletute hulgas oli nii müügimehi, klienditeenindajaid, firmajuhte, laotöölisi, autojuhte kui trükitöölisi. Nad kõik kutsuti intervjuu läbiviimise ajaks siiski otseselt tööpostilt ära eraldi ruumi, kus ei olnud teisi inimesi peale intervjueerija.

\section{Hetketunded}

Katseisikutel paluti loetleda tundeid või emotsioone, mida nad kogesid emotsioonide loetelukatsete seeria vältel. Ülesande eesmärgiks oli saada teada erinevused konkreetsete sündmustega seotud episoodiliste ja üldise kategoorianimetusega seostuvate semantiliste emotsiooniteadmiste käepärasuses (vt Vainik 2001, 2006a).

Tulemused osutasid, et eestlaste semantilistes emotsiooniteadmistes prevaleerivatest emotsioonide põhinimetustest (viha, rõõm, armastus ja kurbus) mainiti hetketunnete loetelukatses olulisel määral vaid rõõmu, seda tegid nii töö juures kui mujal küsitletud (vt tabel 1). Sarnane oli ka see, et mõlemas küsitluskohas nimetati keskmiselt 2,5 emotsiooni.

Erinevused puudutavad loetletud sõnade mitmekesisust: nimelt olid töö juures küsitletute vastused ühetaolisemad (keskmiselt 1,67 erinevat sõna) kui mujal $(1,85)$. Oluline erinevus ilmneb ka emotsioonisõnade hinnangulises aspektis. Situatsioon, kus intervjueerija palus nimetada tundesõnu, on töövälises keskkonnas leidnud vastuvõttu valdavalt positiivsete tunnetega, töökeskkonnas on reageeringute skaala olnud vastuolulisem (vt joonis 1). Tabel 1 esitab hetketunnete loetelukatse tulemused hinnanguliste gruppide lõikes tööl ja mujal. Sealt selgub, et kui mujal on lisaks rõõmule nimetatud uudishimu, põnevust, meeldivust, lõbu ja rahulolu, siis töö juures on tuntud pigem huvi, üllatust, segadust, ebakindlust ja ootusärevust.

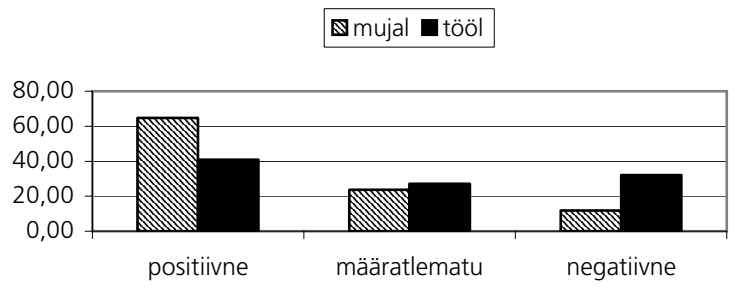

Joonis 1. Hetketunnete loetlemise katse tulemuste protsentuaalne jaotus sõnade tähenduse hinnangulise aspekti alusel 
Tabel 1. Kaks või enam korda nimetatud hetketunnete protsentuaalne jaotus

\begin{tabular}{|c|c|c|c|c|c|c|}
\hline \multirow[b]{2}{*}{ Vastused: } & \multicolumn{2}{|c|}{ Positiivne } & \multicolumn{2}{|c|}{ Negatiivne } & \multicolumn{2}{|c|}{ Määratlematu } \\
\hline & mujal & tööl & mujal & tööl & mujal & tööl \\
\hline rõõm & 11,76 & 4,92 & & & & \\
\hline uudishimu & 5,88 & 2,46 & & & & \\
\hline huvi & 2,94 & 3,28 & & & & \\
\hline üllatus & 2,94 & 3,28 & & & & \\
\hline segadus & & & 1,47 & 4,10 & & \\
\hline ebakindlus & & & 1,47 & 3,28 & & \\
\hline ootusärevus & & & & & 1,47 & 3,28 \\
\hline põnevus & 2,94 & 1,64 & & & & \\
\hline rahulik & 4,41 & & & & & \\
\hline rahu & & 4,10 & & & & \\
\hline rahulolu & 2,94 & 0,82 & & & & \\
\hline lõbus & 2,94 & & & & & \\
\hline meeldivus & 2,94 & & & & & \\
\hline mitte midagi & & & & & 2,94 & \\
\hline tähelepanelikkus & 2,94 & & & & & \\
\hline mõtlikkus & & & & & & 2,46 \\
\hline rahulolematus & & & & 2,46 & & \\
\hline tüdimus & & & & 2,46 & & \\
\hline normaalne & & & & & 1,47 & 0,82 \\
\hline sõbralikkus & 1,47 & 0,82 & & & & \\
\hline väsimus & & & 1,47 & 0,82 & & \\
\hline ärevus & & & 1,47 & 0,82 & & \\
\hline abivalmidus & & 1,64 & & & & \\
\hline armastus & & 1,64 & & & & \\
\hline ei tea & & & & & & 1,64 \\
\hline hämming & & & & & & 1,64 \\
\hline kohusetunne & & & & & & 1,64 \\
\hline lootus & & 1,64 & & & & \\
\hline naljakas & & & & & & 1,64 \\
\hline närviline & & & & 1,64 & & \\
\hline teadmatus & & & & 1,64 & & \\
\hline uimane & & & & 1,64 & & \\
\hline unine & & & & 1,64 & & \\
\hline
\end{tabular}

Märkus: paksus kirjas on esile toodud suurem esiletulek. 
On huvitav märkida, et kuigi nii psühholoogias läbi viidud enesekohaste uuringute tulemused (Veski 1996, Allik 1997) kui emotsioonisõnade lingvistiline analüüs (Vainik 2002a) osutavad, et emotsioonisõnavara saab olla eesti keeles ainult kas positiivse või negatiivse tähendusega, siis hetketunnete loetelukatse vastuste hulgas on märgatav hulk vastuseid, mille hinnangulist valentsi on raske määrata (mitte midagi, mõtlikkus, normaalne, ei tea, hämming, argipäeva emotsioon, tavaline jne). Seega intervjuuga seotud hetkekogemuse kirjeldamiseks ei paistnud eesti keele läbivalt kahevalentsed emotsioonisõnad sobivat ja katseisikud kirjeldasid oma kogemust ligi veerandil juhtudest teisi lingvistilisi vahendeid appi võttes. Üks võimalikke seletusi on see, et emotsionaalse kogemuse kaks karakteristikut intensiivsus ja valents on emotsioonimõistetes omavahel korreleeritud (nt Russell 1980, Russell, Lemay 2000, Zammuner 1998). Olukorras, kus emotsionaalne kogemus ei ole eriti intensiivne või on allasurutud, puudub selle kontseptualiseeringust ka positiivsus-negatiivsushinnang ja seda on raske väljendada tavapäraste emotsiooninimetustega.

\section{Emotsioonidega seotud tegusõnade loetelukatse}

Emotsioonidele on võimalik viidata sõnadega erinevatest sõnaliikidest (vt Vainik 2001), tegusõnu paluti katseisikutel loetleda eesmärgiga teada saada, millistest emotsioonidest meenuvad kergemini tegevuslikku aspekti rõhutavad mõistestused.

Ka katses osalejad lähtusid vastuseid andes rohkem sõna semantikast ja selle (tihti assotsiatiivsest seosest) emotsioonidega, kui küsimuses sisaldunud vormilisest kriteeriumist. Algvormis verbide kõrval (nt vihkama, armastama, kurvastama) nimetati paljudel juhtudel neist regulaarselt tuletatavaid teonimesid (nt kurvastamine) aga ka adjektiive (nt rahulolematu) või nimisõnu, mille seos emotsioonidega on aimatav, kuid seos tegevusliku aspektiga jäi küsitlejale arusaamatuks (nt üksindus). Edaspidi esitatavates näidetes ja loeteludes on vastuste vorm jäetud muutmata.

Tööl on olnud loetelude pikkus keskmiselt 7 sõna (mujal 8,5), vastuste varieeruvus on tööl väiksem (keskmiselt 4,3 erinevat sõna, mujal 5,2) ja ka küsimuse vormilisele kriteeriumile vastas tööl vaid $61 \%$ vastustest (mujal $72 \%$ ). On kaks tõlgendusviisi: kas mittetöine keskkond kuidagi eriliselt soodustas emotsiooniteadmiste aktualiseerimist või on töine keskkond mõjunud küsitletute leksikaalsetele emotsiooniteadmistele filtreerivalt.

Vaba loetelukatse tulemustes on alati sõnu, mis kuuluvad tähenduse poolest otse küsitletud kategooriasse ja sõnu, mis küsitud kategooriaga seostuvad kas assotsiatiivselt või nt põhjuse-tagajärje seose tõttu inimeste tavateadmistes. Tinglikult oli sõnade semantikas võimalik eristada järgnevad rühmad (joonis 2).

Tulemused osutavad, et emotsioonidega otse seostuvate verbide meenumises tööl ja mujal olulist kvantitatiivset vahet ei ole, detailsem vaatlus emotsioonide kaupa artikli järgmises alajaotuses võimaldab aga välja tuua küsitluskohaga seostunud kvalitatiivsed erinevused.

Olulisemad kvantitatiivsed erinevused puudutavad emotsioonidega kas assotsiatiivsetes või kausaalsetes seostes olevate verbide meenumise määra. Tööl 


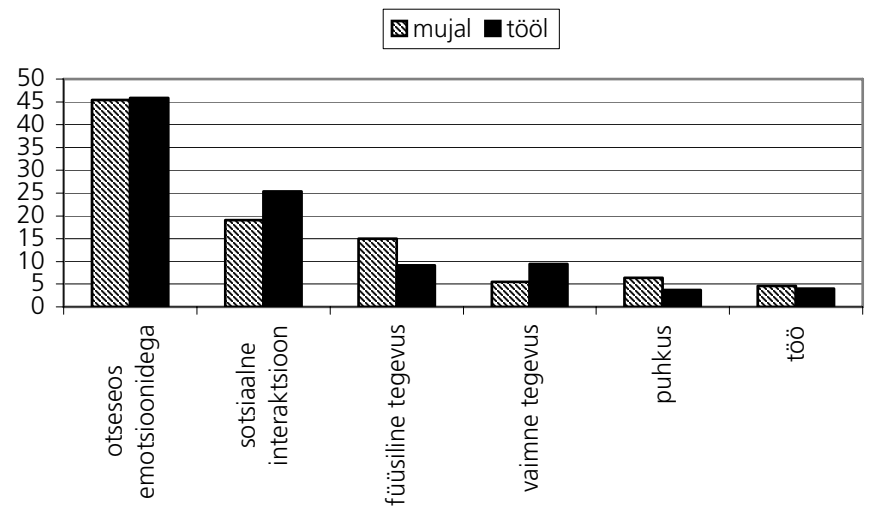

Joonis 2. Emotsioonidega seotud tegusõnade loetlemise katse tulemuste protsentuaalne jaotus peamistesse semantilisesse rühmadesse

küsitletutel on tekkinud need seosed sotsiaalse interaktsiooni ja vaimse tegevusega. Mujal küsitletutel on emotsioonidega suhteliselt rohkem seostunud füïsilised tegevused, puhkus ja kodused tööd. Kõikide olulisemate sõnarühmade võrdlev esiletulek kahes küsitluskohas on esitatud lisas 1. Järgnev kujutab endast nende andmete sisulist avamist ja kommentaari.

\subsection{Emotsioonidega otseselt seostuvate verbide alarühma sisemine liigendus}

Ligi pool vastustest (45\%) nii tööl kui mujal osutasid leksikaalsete emotsiooniteadmiste eri tasanditele (vt lisa 1, semantiline põhigrupp "otseseos emotsioonidega"). Tüüpiliselt väljendavad need sõnad emotsiooni kogemist protsessina, mispuhul emotsiooni mõistestusse kuulub ajaline mõõde.

Töö juures oli suurem osakaal eestikeelsete emotsioonide põhinimetustega viha, armastus, rõõm, kurbus (Vainik 2002a) tuletuslikult seotud sõnadel: armastama, rõõmustama, kurvastama, vihastama, vihkama, rõõmu tundma, rõõmu valmistama. Tööl oli suurem viha ja kurbusega seotud verbide mainimine, mujal tulid meelde armastuse ja rõõmu verbid.

Nii tööl kui mujal olid enim nimetatud emotsioonide prototüüpseid väljendustegevusi kirjeldavad verbid nutma ja naerma. Töö juures on nimetatud ka viha väljendumist tegevusena (raevutsema, märatsema); ornade tunnete avaldamist nimetati enam mujal (kallistama, hellitama, paitama, silitama, musitama, suudlema, õrnutsemine).

Töö juures mainiti ka verbe, mis kuuluvad emotsiooniteadmise põhitasandist üldisemale tasandile (tundma, emotsionaalsus) ja tehti viited emotsioonide regulatsioonile (allasurumine, emotsioonide sissekogumine, enda vaoshoidmine, enesevalitsemine, emotsioonide väljaelamine, sisseelamine) või puudumisele (ükskõiksus).

Mujal küsitletute loeteludes sisaldub rohkem mõisteid emotsiooniteadmiste eritasandilt. Näiteks sõnad, mis osutavad emotsionaalse pinge kasvule ja kahanemisele (erutama, närveerimine, närveldama, kergenduse saamine); seksuaalne veetle- 
vus ja külgetõmme (armuma, ihkama, armatsema, kirge tundma); hedoonilised tegevused (mõnulema, nautima, lõbutsema, joovastuma, joobuma, õnnelik olema, rahuldumine, rahulolu tundmine), kognitiivseid tunded (üllatumine, imestama, imetlema, kahtlema, kahetsema).

Tööl meenusid rohkem sotsiaalsete suhetega seotud emotsioonid (hoolima, kaasa tundma, kadestama, häbenema, austama), sõnad, mis on seotud ohu tunnetamisega (ehmuma, hirmuma, kartma, muretsema); meeleolu langusega (leinama, nukrutsemine, pïnlemine) ja frustratsiooniga (ärritama, rahulolematu, nördima, kibestuma, raevuma).

Mujal küsitletute hulgas tuli esile sõnarühm, kuhu kuuluvad verbid, mis kirjeldavad emotsionaalset kehakeelt (käsi plaksutama, jalgu trampima, ohkama, vilistama, žestid, pöördumine inimese poole) ja näoilmeid (naeratama, muigama, mossitama, grimassitama, silmapilgutus).

Kokkuvõtvalt võib öelda, et kuigi emotsioonidega otseselt seotud (tegu)sõnu meenus tööl ja mujal ühevõrra ja peamised lausutud sõnad olid emotsioonide väljendustegevusi nimetavad sõnad nutma ja naerma, kuulusid tööl meenunud sõnad peamiselt emotsiooniteadmiste üld- ja põhitasandile, kergemini meenusid negatiivsed ja sotsiaalsete suhetega seotud emotsioonid. Mujal loetleti rohkesti emotsiooniteadmiste eritasandile kuuluvaid sõnu ja tuli esile emotsionaalse kehakeele mainimine.

\subsection{Sotsiaalne interaktsioon}

Suurim emotsioonidega assotsiatiivselt või põhjuslikult seotud semantiline põhigrupp, mis nii tööl kui mujal vastajate loeteludest moodustus, oli sotsiaalne interaktsioon (vt joonis 2 ja lisa 1). Enim mainitud sotsiaalse interaktsiooni liigiks oli verbaalne suhtlemine, millest tuleb täpsemalt juttu järgnevas lõigus.

Lisaks on tööl rohkem mainitud kaasinimese aktiivse soodustamise teemat (abistama, abivalmidus, hoolitsema, kaitsma, head tegema, laste kasvatamine, ravima, tohterdama, leevendama) ning huvide konflikti lahendamise strateegiaid (järele andma, andestama, leppima, kavaldama, kompromissi tegema) ja suhtumist kirjeldavaid verbe (sõbrustama, lugu pidama, austama, sallima, ignoreerima).

Mujal küsitletute hulgas tuli emotsioonidega seoses veidi rohkem esile sõnarühm, mis kirjeldab omandussuhetega kaasnevaid asjaolusid (andmine, jagamine, osa saama, saamine, vastu võtma, müümine, ostmine, tingima, maksmine, röövimine, varastamine, leidmine).

\subsubsection{Verbaalne suhtlemine}

Nii tööl kui mujal läbi viidud intervjuudes seostus küsitletute jaoks emotsioonidega verbaalse suhtlemise tegevus, selle sõnarühma osakaal oli aga töises keskkonnas $4 \%$ suurem (vt lisa 1).

Emotsioonidega seostus tööl küsitletute jaoks juba fakt, et suhtlemine toimub (sõnad nagu rääkima, ütlemine, vestlemine, suhtlema, kuulama) ning oluline oli 
ka suhtluskanal (helistama, mobiilile vastama, lugema, kirjutama) ning kõneakti kommunikatiivne funktsioon (küsima, pärima, intervjueerima, vaidlema, kordama, kajastamine).

Mujal küsitletute emotsioonidega seostus tõsiasi, kui ootuspärast verbaalset suhtlemist ei toimu (vaikima, varjama, lõugade kokkusurumine, hambad ristis) või erineb kõneakti sooritusintensiivsus tavapärasest (hü̈̈dma, karjuma, kisama, möirgama, sosistama); samuti verbid, mis tähistavad emotsioonide vastastikust verbaalset väljaelamist, nt nääklema, nägelema, rïdlema.

Keelelise suhtlustegevuse kirjeldamist on peetud pragmaatika pärusmaaks (Õim 1986). Selle paradigma raames on väidetud, et verbaalse suhtluse puhul kavandatakse ja tehakse sõnadega tegusid (Austin 1962). Kõneakte nimetavate verbide esiletulek emotsioonidega seostuvate tegusõnade loetelukatses räägib sellest, et eesti keele tavakasutajagi liigitab verbaalse suhtluse olulise ja emotsioone mõjutavate tegude alla. Töises keskkonnas küsitletud isikute jaoks on osutunud eriti kergesti meenuvaks kõneteod, mis sisaldavad hinnangut. Kuigi kõneakti hinnanguline iseloom seostus emotsioonidega ka mujal, on tööl sedasorti suhtlus meenunud märksa enam (vt joonis 3).

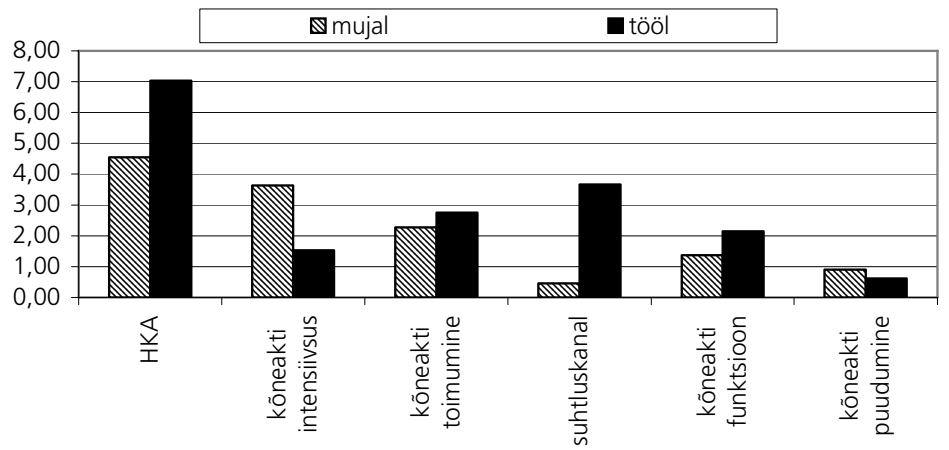

Joonis 3. Emotsioonidega seostatud verbaalse tegevuse aspektide protsentuaalne esiletulek; HKA - hinnanguline kõneakt

Hinnangulist kõneakti (HKA) on defineeritud kui partneri emotsionaalse seisundi mõjutamise akti, mis on suunatud kõneleja suhtluseesmärgi saavutamisele (Volf 1985). Seega on hinnangulise suhtluse puhul emotsionaalse mõjutamise komponent olemuslik ning HKA-de assotsiatiivne seostumine loetelukatse teemaga igati ootuspärane. Näiteks on tööl loetletud verbe, mis nimetavad kõneakte, millega taotletakse muutust partneri emotsionaalses seisundis, olgu siis kas positiivset (kiitma, vabandama, tänama) või negatiivset (laitma).

Kõneaktide teoorias on eristatud lausungit, selle suhtluseesmärki ja taotletavat mõju partneris (Austin 1962, Searle 1969). Nii ongi uuritavate verbirühmade semantikas olulisel kohal ühelt poolt verbiga kirjeldatava kõneakti propositsioonis olev hinnang (miski on hea/halb) ning lisaks kõneaktile omistatav emotsionaalne illokutiivjõud ja/või perlokutiivne efekt. Näiteks kiitus Tubli töö! sisaldab propositsioonis positiivset hinnangut ja selle eesmärk (illokutiivjõud) on adressaati innustada. Kui innustumine toimub, siis on see kõneakti perlokutiivne efekt. Ka kiitja emotsionaalne seisund peab vaikimisi olema positiivne või vähemalt neut- 
raalne, vastasel korral tõlgenduks antud kõneakt irooniana (vt Vainik 1990, Volf 1985).

Loetelukatses mainitud tegusõnad toovad esile teisigi aspekte hinnanguliste kõneaktide võimalikest alussituatsioonidest. Osa sõnadest loetelukatses nimetavad kõnesituatsioone, kus eeldatav kõneleja on ise mingis emotsionaalses seisundis ja "elab seda välja" hinnanguna partnerile, eesmärgiga muuta tema emotsioone kindlas suunas. Näiteks naljatama tähistab olukorda, kus üks kõnesituatsiooni osalistest on heas tujus ja tahab ka partneri tuju tõsta. Negatiivsete tunnete ülekandmine negatiivse hinnangu abil kajastub sõnades, nagu pahandama, kurjustama, õelutsema, õiendama, solvama, sõimama, parastama, mõnitamine, halvustama. Halvas tujus olles teises positiivse hoiaku tekitamise üritamist kirjeldavad verbid õigustama, targutama. Emotsioonide väljaelamist eemärgiga esile kutsuda kaastunnet kirjeldatakse konnotatiivselt hinnanguliste verbidega, nagu halama, hädaldama, kaeblema, vinguma, virisema.

Kokkuvõtvalt võib sedastada, et sotsiaalse interaktsiooni (sh verbaalse suhtlustegevuse ja eriti hinnangulise suhtluse) seostamine emotsioonidega on ootuspärane ja kinnitab autori varasemaid tähelepanekuid, et eestlaste rahvapsühholoogilises intuitiivses suhtlusmudelis on oma koht nii sotsiaalsetel suhetel kui emotsioonidel (Vainik 1987, 2002b). Üllatav on vaid see, et töises keskkonnas on sedasorti sotsiaalset interaktsiooni kirjeldav sõnavara märksa aktiivsem ja käepärasem kui teistes küsitluskohtades. Kui üldiselt on mujal kogutud andmetes olnud suurem mitmekesisus ja väiksem korduvus, siis verbaalse suhtlemise puhul äratab tähelepanu, et tööl on alarühmad hästi mitmekesised, s.t emotsioonidega seostatakse samalaadseid nähtusi, aga eri inimestel eri sõnadega kirjeldatuna.

\subsection{Füüsiline ja vaimne tegevus}

Mujal küsitletute assotsiatsioonides oli ülekaal füüsilistel ja töö juures küsitletutel vaimsetel tegevustel (vt joonis 2 ja lisa 1). Füüsilise tegevuse alla on liigitatud liikumine, füsioloogilised ja aistingutega seotud protsessid ning füüsilised rünnakud. Tööl küsitletud on enam maininud horisontaalset liikumist (jalutama, kõndimine, ujumine, jooksma), mujal küsitletud vertikaalset (hüppama, kargama) või kombineeritud liikumist (tantsima, ronima, kiikuma). Emotsioonidega seostuvate liikumisviiside erinevust eri küsitluskohtades võiks seletada liikumisviiside eeldatava eesmärgipärasuse $v s$. selle puudumisega: töökeskkond on soosinud sihipärast ja mittetöine keskkond lihtsalt lustist liikumist kirjeldavate sõnade meenumist.

Lisaks on mujal meenunud ka keha füsioloogilise toimimisega seotud protsessid (higistama, hingama, magamine, sööma, joomine, palju energiat, seksimine, vananemine, haigestuma), aistingutega seotud (aistima, valu tundma, tõmblus, haigestuma, vigastuma, valutama, vaevlema, pïnlema, väsima, lihaste pingutamine) ja rünnakuid nimetavad verbid, mis võivad olla kas emotsiooni väljaelamine esemetele (laamendama, lõhkuma) või agressioon kaasinimeste suhtes (kägistamine, lööma, kaklema, kerepeale andmine, torkimine).

Vaimsetest tegevustest on nii tööl kui mujal emotsioonidega seoses enam meenunud informatsiooni ümbertöötamine (mõtlema, mõtisklema), mis võib olla ka ebaratsionaalne (mõttelend, unelema, unistama). Tööl on lisaks nimetatud ka 
info ratsionaalse ümbertöötamise viise (analüüsimine, juurdlemine, seostamine) ja info hankimise soovi (huvituma, uudistama, uurimine), info tõlgendamise olulisust (aru saama, taiplikkus, mõistma, mitte aru saama, uskuma, samastama, identifitseerima) ja talletamist (õppima, ei jää meelde). Mujal on enam mainitud info vastuvõttu, kas läbi meeleorganite (vaatama, nägema) või vahenditult (tunnetamine, aimama).

\section{Kokkuvõte ja arutelu}

2001. aastal läbi viidud emotsioonikategooria liikmete loetelukatses ilmnes erinevus tulemuses olenevalt sellest, kas katse viidi läbi töö juures või mujal. Mujal küsitletutele meenusid võrreldava sageduse ja keskpositsiooniga eesti keele neli emotsioonide põhinimetust (armastus, viha, rõõm, kurbus), tööl küsitletutele esmajoones viha ning märksa vähemal määral ülejäänud emotsioonid (Vainik, Orav 2005). Kontrollimaks küsitluskoha mõju loetelukatsete tulemusetele vaadeldi käesolevas artiklis võrdlevalt hetketunnete ja emotsioonidega seotud tegusõnade loetelukatse tulemusi.

Hetketunnete osas selgus, et nii tööl kui mujal nimetati enam rõõmu, tööl sekundeerisid sellele segadus, ärevus, huvi, mujal uudishimu, meeldivus, lõbusus. Tööl küsitletute vastused olid keskeltläbi hinnangu osas vastuolulisemad ja määratlematuma valentsiga, mujal valdavalt positiivsed. Küsitletavate emotsionaalne seisund küsitluse ajal on taustategur, mis võis mõjutada kõikide antud seerias läbi viidud loetelukatsete tulemusi. Milline osa sellest küsitletute hetkeseisundist on tingitud töise vs. muu keskkonna püsimõjust ja milline intervjuuga seotud eriolukorrast, on käesoleva katse andmete põhjal võimatu öelda.

Emotsioonidega seotud tegusõnade osas selgusid semantiliselt seotud sõnarühmad ja ainestiku kvantitatiivne jaotus. Emotsioonidega otseseoses olevate verbide loetelud küll näitavad, millised tunded töö juures prevaleerivad (viha, hirm, frustratsioon, meeleolu langus; sotsiaalsed tunded nagu kaastunne, hoolivus, kadedus, häbi, austus), kuid lasevad ainult oletada nende tunnete põhjusi.

Erinevused emotsioonidega assotsiatiivselt või põhjuslikult seotud sõnavara esiletuleku proportsioonide vahel on kõnekad ja osutavad, et tööl küsitletute jaoks on olnud sotsiaalne interaktsioon, täpsemalt just keeleline suhtlemine üheks emotsionaalsemaks valdkonnaks. Suuga tehtavad "kõneteod" kalduvad töö juures olema suurema emotsionaalse kaaluga kui mujal, lisaks on töises suhtluses emotsionaalne väärtus suhtluse eri kanalitel (telefon, mobiil, arvuti). Veel üheks emotsioonidega enam seostunud valdkonnaks töö juures on vaimsed tegevused, sh nende õnnestumine ja ebaõnnestumine.

Pragmaatika uurijad on personaalses kommunikatsioonis eristanud sisu- ja suhtetasandit, millest sisutasand moodustub lausutavatest propositsioonidest ja suhtetasand partnerite omavaheliste suhete kinnistamisega seotud kommunikatiivsetest eesmärkidest (Watzlawick jt 1967). Töise suhtluse puhul on oletatud sisutasandi ja sellest tulenevalt n-ö infovestluste domineerimist, suhte hoidmise vestlusi on peetud teisejärguliseks (Brown, Yule 2003). Emotsioonide ja suhtetasandi tähtsust interpersonaalses kommunikatsioonis rõhutavad seevastu suhtlustreenerid ja praktikud. Näiteks propageeritakse nn aktiivset kuulamist (Gordon 
2003) ja vägivallatu suhtlemise tehnikat (Rosenberg 2005) ja räägitakse ka nn emotsionaalsest intelligentsusest töise suhtluse kontekstis (Goleman 2001).

Artiklis kirjeldatud loetelukatsetes esile tulnud suhteliselt suur hinnangulistele kõneaktidele osutavate tegusõnade hulk reedab, et töine keskkond on siiski läbi imbunud emotsioonidest ja et hinnang on üheks viisiks, kuidas emotsioonid tööalases keelelises suhtlemises ilmsiks tulevad. Osutus, et ka töö juures me mitte lihtsalt ei kasuta keelt info edastamiseks või selle küsimiseks, vaid mõjutame oma vestluskaaslase seisundit ning anname pidevalt tagasisidet enda emotsionaalse seisundi kohta, sh ka hinnangute abil.

Hinnangulise kõneakti sisuks e propositsiooniks on kas kaudne või otsene hinnang, mis vastab kõneakti sisutasandile. Suhtluseesmärgiks on hinnanguinfo vahendamise kõrval ka kuulaja seisundi, sh emotsionaalse seisundi, mõjutamine (Volf 1985). Hinnang annab suhtluses kas positiivset või negatiivset tagasisidet ja seda nii hinnangu adressaadi tegevuse kui kõneleja emotsionaalse seisundi kohta. Oletan, et kommunikatsiooni suhtetasandil luuakse ja taasluuakse hinnangulise suhtlusega kõnelejate ebavõrdsust. Hinnangud on mõeldavad kontekstis, kus hindaja ja hinnatava staatus on erinev. Tüüpiline näide on kool: õpetaja on see, kes paneb hindeid, pole mõeldav, et õpilane hindaks õpetajat. Hinnanguline suhtlus on üheks viisiks, kuidas kommunikatsiooni suhtetasandil luuakse staatuste vahet, domineerimist ja suhete hierarhiat. Otsekui kompensatsiooniks suhtub keelekollektiiv hinnangulistesse kõneaktidesse omakorda hinnanguliselt, kasutades sellise suhtluse kirjeldamiseks konnotatiivselt negatiivse varjundiga sõnu, nagu näägutama, parastama, õiendama jne. Negatiivsetest emotsioonidest laetud kõneaktide subjektiivne taju on üldistunud negatiivseks hinnanguks, mida sellisele suhtlusele metatasandil omistatakse.

Asümmeetrilisi suhteid loovat kommunikatsiooni on keelelise pragmaatika uurijad omistanud valdavalt meestele, naiselik suhtlemisstiil pidavat kinnistama suhete sümmeetriat ja vastastikusust (Tannen 1990). Võimalik, et viited hierarhilise mudeli olulisusele tööl küsitletute jaoks seostuvad tõsiasjaga, et tööl küsitletute hulgas oli meeste osakaal suurem. Võimalik aga ka, et loetelukatsete tulemustes peegeldub fakt, et enamus töökeskkondi ongi hierarhiliselt organiseeritud ja igapäevane keeleline kommunikatsioon sellises keskkonnas on emotsionaalne eelkõige hinnangute kaudu. Kõneaktide hinnangulisus on nähtavasti viisiks, kuhu töises keskkonnas kanaliseeruvad emotsioonid, millele muidu ehk kohta ette pole nähtudki.

Hierarhiline suhetemudel omakorda diferentseerib emotsioonide väljendamist ja võimalik, et ka kogemist. Näiteks on psühholoogid leidnud, et viha väljendamine seostub staatuste vahega ja Eesti elanike hulgas on leitud tendents, et staatuselt kõrgema või võrdse inimese viha väljendamine on ootuspärane, staatuselt madalam inimene tõenäoliselt oma viha avalikult ei väljenda (Realo jt, käsikiri). On võimalik, et staatuselt madalam isik kogebki võrreldavas olukorras hoopis näiteks frustratsiooni, meeleolu langust või ärevust, tunde kategoriseerimine vihaks võib tunduda kohatu. Väärib edasist uurimist, kas ja mil määral diferentseerib hierarhiline suhetemudel ka teiste emotsioonide väljendamist ja kogemist peale viha.

Lõpetuseks võib öelda, et läbiviimise koht näis tõesti mõjutavat emotsioonisõnade loetelukatse tulemusi, eriti, mis puudutab küsitletud kategooriaga assotsiatiivselt seotud sõnarühmade esiletulekut. Seega leidis artikli alguses püstitatud 
hüpotees vähemalt toetust kui mitte otsest tõestust. Huvitava lisaboonusena andsid loetelukatsed kaudset informatsiooni töises keskkonnas toimuvast verbaalsest kommunikatsioonist. Osutus, et keelelist suhtlemist kasutatakse töises keskkonnas kaugeltki mitte üksnes info edastamiseks, vaid arvatavasti ka staatusega seotud rollisuhete loomiseks ja kindlustamiseks.

\section{Kirjandus}

Allik, Jüri 1997. Psühholoogia lihtsusest. Tartu: Tartu Ülikooli Kirjastus.

Austin, John L. 1962. How to Do Things With Words. Oxford: Oxford University Press.

Brown, Gillian; Yule, George 2003. Teaching the Spoken Language: An Approach Based on the Analysis of Conversational English. Cambridge: Cambridge University Press.

Davies, Ian; Corbett, Greville G. 1995. A practical field method for identifying basic colour terms. - Languages of the World 9 (1), 25-36.

Goleman, Daniel 2001. Töö emotsionaalse intelligentsusega. Tallinn: Väike Vanker.

Gordon, Thomas 2003. Tark lapsevanem. Tallinn: Väike Vanker.

Realo, Anu; van Mechelen, Iven; Allik, Jüri. Dispositional, situational, and cultural determinants of anger experience and expression. Käsikiri autori valduses.

Rosenberg, Marshall B. 2005. Vägivallatu suhtlemine. Tallinn: Nebadon.

Ross, Norbert; Medin, Douglas L. 2005. Ethnography and experiments: Cultural models and expertise elicited with experimental research techniques. - Field Methods 17 (2), 131-149.

Russell, James A. 1980. A circumplex model of affect. - Journal of Personality and Social Psychology 39, 1161-1178.

Russell, James A.; Lemay, Ghyslaine 2000. Emotion concepts. - Michael Lewis, Jeanette Haviland-Jones (Eds.). Handbook of Emotions. Vol. 2. New York: The Guilford Press, 491-503.

Searle, John R. 1969. Speech Acts. An Essay in the Philosophy of Language. Cambridge: Cambridge University Press.

Sutrop, Urmas 2001. List task and a cognitive salience index. - Field Methods 13 (3), 289-302.

Zammuner, Vanda. L. 1998. Concepts of emotion: "Emotionness", and dimensional ratings of Italian emotion words. - Cognition and Emotion 12 (2), 243-272.

Tannen, Deborah 1990. You Just Don't Understand. Women and Men in Conversation. New York: William Morrow and Company, Inc.

Vainik, Ene 1987. Eesti keele suhtlussõnavara liigendus ja keelekasutaja intuitiivne suhtlusmudel. - Dialoogi mudelid ja eesti keel. Töid eesti filoloogia alalt. Tartu Riikliku Ülikooli toimetised 795. Tartu: Tartu Riiklik Ülikool, 106-119.

Vainik, Ene 1990. Tegusõnad sõnade tegemisest. - Keel ja Kirjandus 9, 549-556.

Vainik, Ene 2001. Eestlaste emotsioonisõnavara. Käsikirjaline magistritöö Tartu Ülikoolis.

Vainik, Ene 2002a. Emotions, emotion terms and emotion concepts in an Estonian folk model. - Trames 6 (4), 322-341.

Vainik, Ene 2002b. Kas eestlased on "kuumaverelised"? Eestlaste rahvalikust emotsioonikategooriast. - Emakeele Seltsi aastaraamat 47 (2001). Mati Erelt (peatoim.), Evi Ross, Asta Õim (toim.). Tallinn: Emakeele Selts, 63-86.

Vainik, Ene 2006a. Intracultural variation of semantic and episodic emotion knowledge. Trames 10 (2), 169-189.

Vainik, Ene 2006b. Emotsioonisõnad töises keskkonnas - millest kõnelevad loetelukatsete tulemused? - Ettekanne V rakenduslingvistika kevadkonverentsil "Keel töises suhtluses”, Tallinn, 20.-21. aprill 2006. 
Vainik, Ene; Orav, Heili 2005. Tee tööd ja näe vaeva, ...aga ikka oled vihane. - Keel ja Kirjandus 4, 257-277.

Veski, Epp 1996. Emotsionaalseid seisundeid kirjeldav sõnavara eesti keeles ja selle seos isiksuse omadustega. Käsikirjaline diplomitöö Tartu Ülikoolis.

Volf 1985 = Вольф Елена М. 1985. Функциональная семантика оценки. Москва: Наука.

Watzlawick, Paul; Bavelas, Janet B.; Jackson Don D. 1967. Pragmatics of Human Communication. A Study of Interactional Patterns, Pathologies, and Paradoxes. New York, London: W. W. Norton \& Company.

Õim, Haldur 1986. Pragmaatika ja keelelise suhtlemise teooria. - Keel ja Kirjandus 5, 257-269.

Lisa 1. Emotsioonidega seotud tegu sõnade loetelukatse tulemuste kvalitatiiv-kvantitatiivne jaotus küsitluskoha tüüpide lõikes

\begin{tabular}{|c|c|c|c|c|}
\hline $\begin{array}{l}\text { Semantiline } \\
\text { põhigrupp: }\end{array}$ & Alagrupp: & Täpsustus: & Mujal: & Tööl: \\
\hline \multicolumn{3}{|c|}{ otseseos emotsioonidega } & 45,5 & 45,9 \\
\hline & \multirow[t]{5}{*}{ emotsiooniteadmiste põhitasand } & & 10,5 & 13,2 \\
\hline & & viha & 1,8 & 4,9 \\
\hline & & armastus & 3,2 & 3,1 \\
\hline & & kurbus & 1,4 & 1,8 \\
\hline & & rõõm & 4,1 & 3,4 \\
\hline & emotsiooniteadmiste üldtasand & & 1,4 & 4,3 \\
\hline & \multirow[t]{9}{*}{ emotsiooniteadmiste eritasand } & & 12,3 & 11,9 \\
\hline & & sotsiaalsed & 0,5 & 3,4 \\
\hline & & hedoonia & 3,6 & 1,5 \\
\hline & & ohuolukorrad & 1,4 & 2,5 \\
\hline & & külgetõmme & 1,8 & 1,2 \\
\hline & & muutused pinges & 1,8 & 0,9 \\
\hline & & kognitiivsed & 2,3 & 0,3 \\
\hline & & frustratsioon & 0,9 & 1,2 \\
\hline & & meeleolu langus & & 0,9 \\
\hline & \multirow[t]{5}{*}{ väljendustegevused } & & 17,7 & 14,1 \\
\hline & & armastus & 4,6 & 1,5 \\
\hline & & rõõm & 7,3 & 5,5 \\
\hline & & kurbus & 5,0 & 4,9 \\
\hline & & viha & 0,9 & 2,1 \\
\hline & emotsionaalne kehakeel & & 3,6 & 2,5 \\
\hline
\end{tabular}




\begin{tabular}{|c|c|c|c|c|}
\hline $\begin{array}{l}\text { Semantiline } \\
\text { põhigrupp: }\end{array}$ & Alagrupp: & Täpsustus: & Mujal: & Tööl: \\
\hline \multicolumn{3}{|c|}{ sotsiaalne interaktsioon } & 19,1 & 25,4 \\
\hline & \multicolumn{2}{|l|}{ verbaalne suhtlemine } & 13,2 & 17,7 \\
\hline & & suhtluskanal & 0,5 & 3,7 \\
\hline & & hinnangusuhtlus & 4,5 & 7,0 \\
\hline & & kõneakti funktsioon & 1,4 & 2,1 \\
\hline & & kõneakti intensiivsus & 3,6 & 1,5 \\
\hline & & kõneakti toimumine & 2,3 & 2,8 \\
\hline & & kõneakti puudumine & 0,9 & 0,6 \\
\hline & omandussuhted & & 2,3 & 2,1 \\
\hline & aktiivne soodustamine & & 1,4 & 1,8 \\
\hline & huvide konflikti lahendamine & & 1,4 & 1,8 \\
\hline & suhtumine & & 0,5 & 0,9 \\
\hline \multicolumn{3}{|l|}{ füüsiline tegevus } & 15,0 & 9,2 \\
\hline & \multicolumn{2}{|l|}{ liikumine } & 7,3 & 4,3 \\
\hline & & vertikaalne & 3,2 & 0,6 \\
\hline & & horisontaalne & 0,9 & 2,1 \\
\hline & & kombineeritud & 1,8 & \\
\hline & füsioloogia & & 2,7 & 1,8 \\
\hline & aisting & & 2,7 & 1,5 \\
\hline & rünnak & & 2,3 & 1,8 \\
\hline \multicolumn{3}{|l|}{ vaimne tegevus } & 5,5 & 9,5 \\
\hline & info tõlgendamine & & & 2,8 \\
\hline & info ümbertöötamine & & 2,3 & 3,4 \\
\hline & info vastuvõtt & & 2,3 & 1,8 \\
\hline & info hankimine & & 0,9 & 0,9 \\
\hline & info talletamine & & & 0,6 \\
\hline \multicolumn{3}{|l|}{ puhkus } & 6,4 & 3,7 \\
\hline & aktiivne & & 5,9 & 2,1 \\
\hline & passiivne & & 0,5 & 0,9 \\
\hline & üldine & & & 0,6 \\
\hline \multicolumn{3}{|l|}{ töÖ } & 4,6 & 4,0 \\
\hline & spetsiifiline & & 3,2 & 0,6 \\
\hline & üldine & & 1,4 & 3,4 \\
\hline
\end{tabular}

Märkus: numbrid lahtrites "tööl" ja "mujal" tähendavad sõnade esiletuleku protsentuaalset osakaalu vastavas alajaotuses. Poolpaksus kirjas on esile tõstetud read, kus erinevus on suurem või võrdne 2,5\%-ga.

Ene Vainiku (Eesti Keele Instituut) uurimisobjektiks on eesti keele emotsioonisõnavara, selle struktuur, semantika ja varieerumine. Huvipakkuvateks teemadeks on ka psühholingvistika, kognitiivne semantika ja keele ning emotsioonide interaktsioon laiemalt. Täiendanud ennast praktilise psühholoogia alal. ene@eki.ee 


\section{EMOTION TERMS AT WORK - \\ WHAT DO THE RESULTS OF TASKS OF FREE \\ LISTING REVEAL ABOUT?}

\section{Ene Vainik}

Institute of the Estonian Language

The paper focuses on a comparison of the results of tasks of free listing of emotion terms as carried out at work and at leisure. The working hypothesis was that the environment where the task is carried out could also influence the results, at least as far as the task involves listing emotion-related terms.

As a result of semantic analysis of the elicited emotion terms and associatively related vocabulary it occurred, indeed, that the topicality of emotion knowledge varied according to the environment where the task was carried out. Presented and discussed are the results of two tasks - the task of listing one's own current emotions during the task and the task of listing emotion-related verbs.

It turned out that the main difference between the emotion terms elicited at the working place vs. at leisure lay in their evaluative value. Most of the terms listed at leisure referred to positive emotions, while terms elicited at work were both positive and negative. In addition, it was found that the participants had some difficulty in categorizing their current emotions by means of Estonian bi-valent emotion terms. In remarkably many cases the participants turned to lexis other than emotion terms to describe their current feelings.

The task of listing emotion-related verbs revealed different topicality of phenomena related with emotions associatively and causally. At work it occurred that acts of verbal communication and intellectual actions were mentioned much more frequently, while at leisure it was rather physical actions, leisure and housework.

A remarkably big part of the vocabulary referring to speech acts was evaluative by nature. The possible meaning of such asalient amount of evaluative communication emerging at the working place and its topicality for emotions was discussed by means of the theory of pragmatics. It was further hypothesized that emotionally relevant evaluative communication might be related to the hierarchical pattern of relations holding default in most working places. Thus, communication at work is hardly a pure exchange of information - this is what the tasks of free listing of emotion terms mostly revealed about.

Keywords: anthropological linguistics, semantics, pragmatics, Estonian 